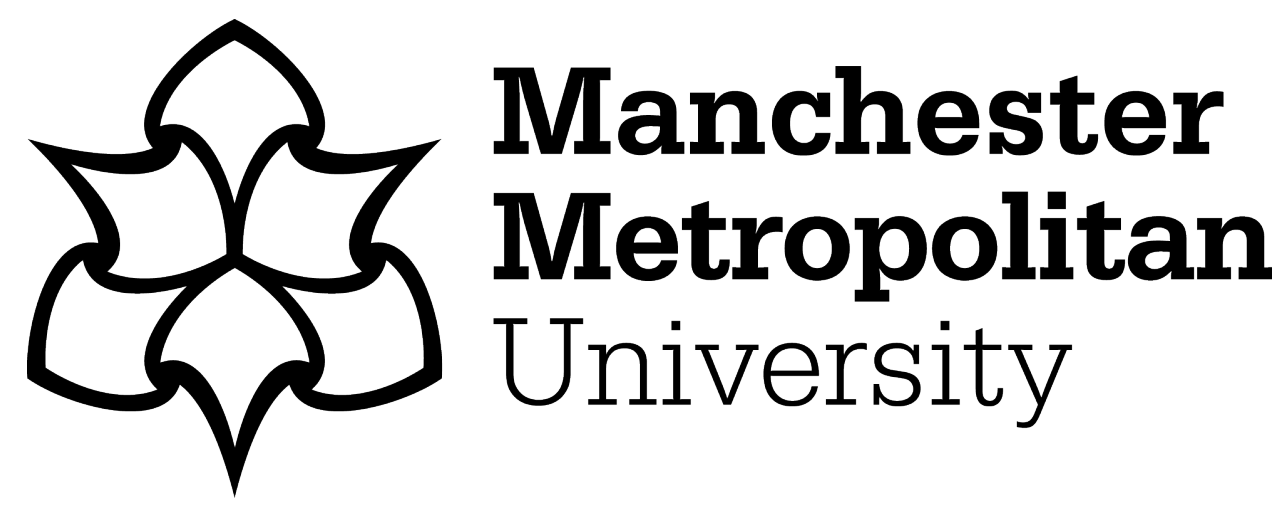

Menendez Alvarez Hevia, David and Sant, Edda (2018) Policy and Research on Citizenship Education in the United Kingdom (1998-2018). In: Handbook of Research on Education for Participative Citizenship and Global Prosperity. IGI Global, pp. 302-327. ISBN 1522571108

Downloaded from: https://e-space.mmu.ac.uk/621741/

Version: Accepted Version

Publisher: IGI Global

DOI: https://doi.org/10.4018/978-1-5225-7110-0

Please cite the published version 


\section{Handbook of Research on Education for Participative Citizenship and Global Prosperity}

José A. Pineda-Alfonso (University of Seville, Spain), Nicolás De Alba-Fernández (University of Seville, Spain) and Elisa Navarro-Medina (University of Seville, Spain)

Projected Release Date: November, 2018 Copyright: @ 2019 Pages: 525

ISBN13: 9781522571100 ISBN10: 1522571108 EISBN13: 9781522571117 DOI: 10.4018/978-1-5225-7110-0

\section{Description}

Active participation in processes of change are an essential aspect of community participation, and proper recognition of opportunities for participation facilitate community engagement nationally and internationally. Education and its relation to citizenship in recent years has become one of the most important fields of research. From different areas and contexts, it has been revealed that there is a prevailing need for education for citizens to take part actively in the processes of change and improvement that the current global situation requires.

The Handbook of Research on Education for Participative Citizenship and Global Prosperity is a pivotal reference source focusing on the productions and fields of study that are carried out all over the world on education for citizenship, namely the devices that provide young people with the consciousness and highlight the aspects of an active democratic life. While highlighting topics such as citizenship identity, educational policy, and social justice, this publication explores participation instruction, as well as the methods of community involvement. This book is ideally designed for educational administrators, policymakers, researchers, professionals, and educators seeking current research on instructional methods for teaching active community and political involvement.

\section{Contribution:}

\section{Chapter 13}

Policy and Research on Citizenship Education in the United Kingdom (1998 - 2018)

Edda Sant, David Menendez Alvarez-Hevia

This chapter explores citizenship education in the United Kingdom with a particular focus on the major policy and research trends of the last twenty years (1998-2018), particularly in relation to school and non-school based citizenship education. This discussion is articulated in relation to dimensions (i.e. global and national), approaches (i.e. character, social justice and democratic education) and spaces. The last section of this chapter illuminates some key issues for citizenship education in the UK and how these can help us to understand what might happen everywhere else.

\section{Introduction}

This chapter explores citizenship education in the United Kingdom. The particular focus is on the major policy and research trends of the last twenty years (1998-2018), particularly in relation to school and non-school based citizenship education for primary and secondary school students.

The question of citizenship -and citizenship education- in the UK has been highly convulsed during these two decades. In 1998, the Good Friday Agreement between 
most of Northern Ireland's political parties, the British and the Irish Government lead to a greater stability in Norther Ireland ending with the thirty-year periods of violence and repression often known as the 'Troubles'. Simultaneously, the Labour Government of Blair had been recently elected (1997) with the promise of 'devolving' autonomous institutions to Wales and Scotland. The process of devolution transferred competences from central government to the 'national' governments of Scotland, Wales and Northern Ireland (Andrews \& Mycock, 2007). The jurisdiction in England was kept on the hands of the UK Parliament. Since then, the relevance of national/regional parties have grown. Arguably, the most well-known case has been Scotland where a Referendum for the Independence took place in $2014^{1}$. Devolution, however, has not satisfied everyone. Since 1997, some English nationalists have argued that the process is unfair, with rules applying to England been decided in the UK Parliament including political representatives from the 'four nations' (see e.g. Seth-Smith, 2013). English nationalism has also grown feeding parties and organizations such as UKIP, avant-gardes of Brexit. This has more recently led to the results of the United Kingdom European Union membership referendum (2016) showing clear in-country differences (e.g. whilst 53.38\% of the English voters voted 'Leave', only $38.00 \%$ of the Scottish voters did).

UK is a highly diverse country, in both social and regional terms. Let's take as an example the different ways in which Britons relate with the (often) controversial notion of Britishness (see e.g. Smith, 2016). Although questions of national identity are always complex, Britishness in the UK appears to be distinctively conceived by ethnic and regional groups. Kymlicka (2011), for instance, explains:

"when the 2003 UK Home Office Citizenship Survey asked 'how strongly you belong to Britain', 85.95 per cent of Indians, 86.38 per cent of Pakistanis, and 86.85 per cent of Bangladeshis said that they belong either 'fairly' or 'very' strongly to Britain - numbers that are essentially identical to the 86.7 per cent of whites who said they either fairly or very strongly belong. (...) By contrast, only 8.5 per cent of Catholics in Northern Ireland identify as British (Coakley, 2007). That may be an exceptional case, but Scots too are less likely than immigrants to identify as British - a seemingly stable 33 per cent of Scots reject even a partial British identity (Bond and Rosie, 2002)." (pp. 284-285)

Diversity in the UK does not only apply to the social, political and economic landscape but also to educational policy, practice and research. Educational policy, practice and even research are very different in each of the four nations. The UK does

\footnotetext{
${ }^{1} 44,70 \%$ of the voters voted 'Yes', and $55,30 \%$ voted 'No'.
} 
not have a common policy but rather each region has its own educational jurisdiction (Colley, 2007). Key principles such as compulsory schooling entry age, higher education fees and the primary and secondary curriculum have historically differed (and still do) from one nation to the other (Phillips, 2010). In this context, citizenship education policy and practice are highly diverse, and this diversity also impacts upon research conducted on this area.

This chapter is structured as follows. The educational policy related to citizenship education for each of the four nations is first examined. The analysis begins with the Crick Report's recommendations of 1998, often named as one of the key frameworks framing citizenship education in England but also elsewhere (e.g. Farthing, 2010; Husbands, 2007; Maes \& Vanheeswijck, 2005; Rodrigo, 2014). This is followed by a consideration of the key themes emerging from citizenship education research conducted in the UK context. Particularly, the focus is on highlighting the dimensions, approaches and spaces articulating educational research in citizenship education. We conclude by exploring some key issues for citizenship education in the UK and how these can illuminate what happens everywhere else.

\section{Policy: the context for citizenship education in England, Wales, Scotland and Northern Ireland}

In this section, an overview of policies related to citizenship education (from 1998 2018) for each of the four nations is provided. Although there are some similarities (for instance between Scottish and Welsh approaches), following the previous comments on the autonomy of each educational jurisdiction, this section is divided in four parts.

\section{England}

The Advisory Group for Citizenship Report (DfEE/QCA, 1998), often known as the Crick Report, is the first key citizenship education-related policy in England. After the Labour victory in the general election of 1997, the Secretary of State for Education and Employment, David Blunkett, established the Advisory Committee on citizenship and the teaching of democracy in schools. The rationale for the Committee was, as Kerr (2005) explains,

"[the] growing concern, in particular, about the rapidly changing relationships between the individual and the government and the decline in traditional forms of civic cohesion: what has been termed a 'democratic deficit'". (p. 97)

The Committee, led by Professor Bernard Crick (a former professor of Blunkett) (Davies \& Issitt, 2005), recommended to strengthen citizenship education through three major strands: (a) social and moral responsibility; (b) community involvement 
and (c) political literacy (DfEE/QCA, 1998). The recommendations were accepted by the Labour government and a citizenship education framed through these three strands became a National Curriculum subject in 2002 (Davies, 2014). Citizenship was embedded within the non-statutory framework for Personal, Social and Health Education (PSHE) for students aged 5-11 and a new curriculum subject for students 11-16 was created (Kerr, 2005). After some years of application, many considered that citizenship education had been a success (Davies, 2014; Keating et al., 2010).

The new curriculum for citizenship education and the way in which was actually implemented in schools was, nevertheless, criticized from both left and right-hand perspectives. On the left, scholars, practitioners and activists denounced the report's failure to tackle the issue of equality and disadvantage (Faulks, 2006a; Olssen, 2004). For instance, concerns were raised to the limited references to cultural diversity and the absence of discussions on racism (Faulks, 2006a; Osler \& Starkey, 2001). In terms of curriculum practice, the Report was described as been "indecisive" (Faulks, 2006a, p. 127) in defining how citizenship should be integrated in school-based practice. Although the curricular aims were statutory, approaches to citizenship education were extremely variable from school to school (Kerr, 2005) (e.g. citizenship as a subject, citizenship as cross-curricula or integrated in other subjects) (see Sant et al., 2018b). An inspection report from 2005 (Ofsted, 2005) described,
"A minority of schools have established a discrete core programme taught by a small group of specialists, the latter including recruits drawn from the new citizenship PGCE courses. More frequently, citizenship is a significant partner with PSHE or other subjects, usually being taught in distinctive modules. This core is augmented, for example, by participation and responsible action on activity days and through the work of a democratic school council." (p. 4)

On the right, the conservatives had longed argued against the possibility of the state taking a direct role in the political education of citizens (Faulks, 2006a). The possibility of indoctrination of children by teachers (Faulks, 2006a) and the emphasis of the family, rather than the state, to provide citizenship education (McLaughlin, 2000) were the main arguments putted forward.

Considering these critiques, it is not surprising that, when the UK conservative government regained power on 2010 (under a Government coalition), many felt that citizenship education would be removed from the National Curriculum of England (Davies, 2014). Ultimately, citizenship education remained but the policy shifted in four ways. First, the national curriculum for citizenship education was modified and 'financial literacy' was included as a key aspect of citizenship (DfE, 2013). Second, budget cuts were implemented in citizenship education organizations and research 
(Davies, 2014). Third, community involvement was separated from school-based practices. The trust-lead National Citizenship Service (NCS) is now expected to provide opportunities for young people's community engagement (Davies \& Chong, 2016). Fourth, the new coalition government implicitly created a new cross-curricula approach to citizenship education through the controversial requirement that schools should promote Fundamental British Values (FBV). Embedded as part of the anti-terrorist and anti-radicalization Prevent policy, schools in England have the duty to 'actively promote' the FBV of democracy, the rule of law, individual liberty, and mutual respect and tolerance of those with different faiths and beliefs (see Arthur, 2015) through different "actions" such as "include in suitable parts of the curriculum (...) advantages and disadvantages of democracy" (DfE, 2014a, p. 6). As one of us has explained somewhere else,

"The promotion of British Values here is defined from a cross-curricular [citizenship education] perspective, incorporating both the 'cognitive' (i.e. knowledge, skills) and 'affective' (i.e. values, practices) domains of citizenship education (Peterson, 2011). All student teachers are therefore expected to contribute at least to the affective domain through their pedagogical practices, creating an open classroom climate and a democratic school ethos." (Sant \& Hanley, forthcoming)

The new focus has also been subject to major critiques. It has been argued that the lack of resources might have dangerously damaged the successful prospective of the 2002 emphasis on citizenship education (Davies \& Chong, 2016). In addition, as we shall discuss later, a large number of scholars have also demonstrated their discontent with the national orientation of the new approach on FBV arguing against the exclusionary character of the policy and associated inspection practices (e.g. Arthur, 2015; Elton-Chalcraft, Lander, Revell, Warner \& Whitworth, 2017; Jerome \& Clemitshaw, 2012).

\section{Wales}

The Devolution process did not result in the introduction of a new Curriculum subject in Citizenship education in Wales. However, the Welsh Assembly Government, since its creation, has strongly encouraged a cross-curricula and integrated approach to citizenship education through three distinctive features, (1) the 'Welshness' of the curriculum, (2) the subject Personal and Social Education (PSE) and (3) the crosscurricula emphasis on Education for Sustainable Development and Global Citizenship.

According to Andrews and Mycock (2007), "the Welsh Assembly Government did not seek to establish statutory citizenship education because it was focused on developing institutions and building good relations with local authorities" (p. 76). The 
new Welsh Curriculum - the Curriculum Cymreig (CC) - prioritized the 'Welshness' of the curriculum. Across all curriculum subjects, students are expected to study cultural, economic, environmental, historical and linguistic characteristics of Wales (Philips, 2004). The emphasis is here placed on cultural and civic 'Welshness' (Andrews \& Mycock, 2007). If as Davies (2014) argues, Welsh nationalism tend to be cultural rather than political, it is not surprising that of the curriculum responds to the same perspective.

Perhaps more explicitly related to citizenship education in itself, Personal and Social Education (PSE) is a compulsory subject for students aged 7 to 19 . Similarly to the English PSHE, PSE aims to prepare students in a wide range of social knowledge, skills and values including to:

" empower learners to participate in their schools and communities as active responsible citizens locally, nationally and globally

- foster positive attitudes and behaviour towards the principles of sustainable development and global citizenship" (Welsh Assembly, Department for Children, Education, Lifelong Learning and Skills, 2008a, p. 4).

PSE is not only a subject but it is also expected to be a 'holistic approach' to the curriculum (Welsh Assembly, 2008a). All teachers, regardless of their level and subject, are expected to be involved. The framework identified five different themes, two of which explicitly relate to citizenship education: active citizenship and Sustainable development and global citizenship. In the case of active citizenship, the emphasis is on students learning by practicing (Kitchen, 2005). Activities such as participation on school councils and community actions are encouraged (Welsh Assembly, 2008a). As in the English context, this detailed framework is not compulsory for schools to implement (Davies, 2016).

Education for Sustainable Development and Global Citizenship (ESDGC) is both a theme within PSE as well as a cross-curricula policy in its own (Welsh Assembly, 2008b). ESDGC is articulated around seven major themes (wealth and poverty, identity and culture, choices and decisions, health, climate change, consumption and waste and natural environment) that can be explored in different ways by each particular school. However, ESDGC is expected to be integrated in the leadership, management and teaching and learning activities within all schools across Wales (Welsh Assembly, 2008b) and the compliance with the policy is inspected by the education and training inspectorate for Wales (ESTYN) (Davies, 2016). In practice, the cross-curricula perspective appears to have had a major impact in certain curricula subjects, particularly geography (Robbins, Francis \& Elliott, 2003). 


\section{Scotland}

The civics related subject 'Modern Studies' - examining social, economic and political issues - had existed in Scotland since 1959 (Munn \& Argott, 2009). Whilst this subject might explain why citizenship education has not become a separate subject (Davies, 2014), it also might help us to understand why the introduction of citizenship education frameworks in the Scottish context is often considered to be smother than in the English one (Andrews \& Mycock, 2007).

The establishment of the Education for Citizenship Review Group in 1999 represents the first impetus on citizenship education in the period here studied (Davies, 2014). The group published in 2002 the Education for Citizenship in Scotland report. According to Biesta (2008), the central ideal of the paper is,

"'that young people should be enabled to develop capability for thoughtful and responsible participation in political, economic, social and cultural life' (LTS 2002: 3). This is said to depend on development of four aspects: 'knowledge and understanding, skills and competence, values and dispositions and creativity and enterprise' (ibid)." (p. 40)

The paper established the basis of the way citizenship education is conceived in Scotland. Similarly to what we have discussed in the case of Wales, in Scotland, young people are understood to learn about citizenship by practicing citizenship in their communities (Biesta, 2008). As Maitles (2010) explains, the key idea is that "young people are citizens now, not citizens in waiting" (p. 391). As in Wales, the emphasis is also placed on the identification and responsibility with the community (Andrews \& Mycock, 2007; Biesta, 2008).

These two principles underlie citizenship education as framed on the 2004 Scottish Curriculum for Excellence. The Curriculum for Excellence set the purposes and expected outcomes for all students aged 3-18 in Scotland. The Curriculum places particular emphasis on the education of responsible citizens. It explicitly manifests that,

"The purpose of the curriculum is to help children and young people to become successful learners, confident individuals, responsible citizens and effective contributors." (The Scottish Government, 2008, p. 11).

As in the case of Wales, the curriculum emphasizes the need of schools tackling citizenship education across subjects as well as the whole school informal curriculum (Cowan \& McMurtry, 2009). Across subjects, history, geography and more particularly modern studies, take a key relevant role. In addition to this, children and young people are encouraged to participate in school and community-based actions such as young people's councils, school twining, fundraising, etc. 
In brief, in his analysis of the Scottish policy on citizenship education, Biesta (2008) identifies four characteristics that, in his understanding, frame the contemporary Scottish approach to citizenship education. These are: (1) individualistic tendency, (2) a broad understanding (political, cultural, economic and social) of citizenship, (3) an emphasis on action including active citizenship and experiential learning and (4) a prioritization of the links of citizens with local and in some occasions global communities.

\section{Norther Ireland}

The situation of citizenship education in Norther Ireland has been strongly influenced by the 'Troubles' and by the 1998 Good Friday Agreement that ended that period (Davies, 2014). The Agreements, for instance, explicitly mentioned the need to promote a 'culture of tolerance' (Smith, 2003). As a result of this, different working groups were established resulting on the publications of two key reports for the future of Northern Irish citizenship education: 'Integrating Education' that affirmed the need of a 'pluralist approach to education' and 'Education for Diversity' that focused on the improvement of community relations (Smith, 2003).

The new Curriculum for Northern Ireland in 2007 gathered the focus on social cohesion emerging from these previous reports. According to Niens and Chastenay (2008), the new program,

"was modeled on similar initiatives in the Republic of Ireland, England, Scotland, and Wales (Kerr, McCarthy, and Smith 2002) and was based on research findings indicating a need for a human rights framework, greater understanding of democracy and cultural diversity, and the development of active participation skills (Gallagher and Smith 2002)." (p. 525)

Similarly to the PSE Wales and the PSHE in England, citizenship education was here embedded within more generic subjects. For children aged 5-11, citizenship education is integrated within the subject 'Personal Development and Mutual Understanding'. The subject aims to encourage children "to become confident, independent and responsible citizens, making informed and responsible choices and decisions throughout their lives" (CCEA, 2007a, p. 3). Diverse themes such as 'rules, rights and responsibilities', 'similarities and differences' and 'managing conflict' are tackled through issue-based and participatory learning strategies.

Students aged 11-16 take a subject called 'Learning for Life and Work' (LLW). The subject is articulated around four major areas one of which is 'Local and Global citizenship'. Local and Global Citizenship is based on the themes of Human Rights and Social Responsibility, Diversity and Inclusion, Equality and Social Justice and Democracy and Active Participation that are expected to be addressed in local, 
national, European and global contexts (CCEA, 2007b). Similarly to the primary curriculum, the discussion of controversial issues and experiential learning activities are encouraged.

With a main focus on social cohesion (McMurray \& Niens, 2012), citizenship education in the Northern Irish policy appears to be constructed in relation to three key features. First, issues related to identity, conflict and reconciliation are particularly prominent (McMurray \& Niens, 2012; Niens \& Chastenay, 2008) if compared to the way citizenship education is constructed in the other three nations. The Northern Ireland case is, indeed, often presented as an example of citizenship education in a post-conflict society. Second, Human Rights are understood to provide the 'value base' of any citizenship-related discussion (Niens, O'Connor \& Smith, 2013). Human Rights are considered globally accepted values, particularly in its mentions to peace (Niens \& Chastenay, 2008). And third, citizenship education is conceived as an inquiry-based area (McMurray \& Niens, 2012; Niens \& Chastenay, 2008).

Controversial issues are understood as the key educational strategy to encourage conflict management and deliberation (Niens et al., 2013).

\section{Research: key themes}

This section focuses on some key themes emerging from theory and research in citizenship education in the UK context. The section is organized in relation to the dimensions (national and global), the approaches (character, social justice and democratic education) and the spaces (the interconnection between school and community) of citizenship education discussed by relevant authors on the field.

\section{The dimensions: global and national}

The influential Crick Report (DfEE/QCA, 1998) explicitly identifies United Kingdom, Europe, the Commonwealth and the world as key dimensions of citizenship. In the last two decades, nevertheless, the 'global' and the 'national' dimension have become prominent in citizenship education policy, theory and research in the UK. Thus, in this section, the focus is on how the 'global' and the 'national' dimension are constructed and practiced, examining the similarities and differences in each of the four nations.

Global citizenship. Educational researchers have largely analyzed the way 'global citizenship' and 'global citizenship education' are discursively constructed in UKbased policy and practice. Scottish citizenship education related policies - particularly the Curriculum for Excellence but also other governmental recommendations derived from this - have been critically examined to uncover potential underlying ideologies (Biesta, 2008; Gamal \& Swanson, 2017; Swanson \& Pashby, 2016). Researchers have emphasized how the policies are constructed in relation to neoliberal principles. 
Students, for instance, are expected to be 'equipped' with certain skills and knowledge reinforcing a particular individualistic, economic-based and instrumentalist approach to citizenship education (Gamal \& Swanson, 2017; Mannion et al., 2011; Swanson \& Pashby, 2016;). The logic here also relates to human capital principles and the role of Scotland in a globalized world. When 'equipped' with these skills, learners might be able to make stronger contributions for the economic 'flourishing of Scotland' (Gamal \& Swanson, 2017). Simultaneously, the Scottish policies are also constructed in relation to liberal cosmopolitanism and its emphasis on consensus. As described by Biesta (2008), in the documents "'community' (also the global community) is used as an unproblematic notion and generally also as a positive notion" (p. 46). The global community appears to be understood as homogeneous and uncontroversial.

In England, the role of the 'global' dimension of citizenship education is more ambiguous. Discussions on global education and on citizenship education have been disconnected to each other for a long time (Davies, Evans \& Reid, 2005). Under the Blair's Government, there was a serious attempt to bring the 'global dimension' in schools (DfE, 2005) -including some mentions to global citizenship - but this attempt appears to have been paralyzed by the more nationally-orientated policies putted forward by the Coalition and the Conservative governments. Even so, a number of researchers have examined how global citizenship is constructed in the policy and practice documentation. Whilst in practice-orientated documentation, the focus appears to be on active citizenship; in policy documentation there is a stronger emphasis on citizenship knowledge and skills (Ibrahim, 2005). In both types of documents, nevertheless, two major discourses are merged to construct global citizenship (Camicia \& Franklin, 2011). On one end, a neoliberal discourse that, as in the case of Scotland, emphasises the skills and the potential economic contribution of citizens (Marshall, 2011). On the other, a more democratic-orientated discourse that focuses on fostering identification with the global community, social justice and recognition values (Camicia \& Franklin, 2011). A deep analysis of one of the documents reveals how both discourses interact:

"the outcomes within both cultural and critical GC focus on celebrating diverse cultures, challenging stereotypes and critiquing negative images of so-called 'less economically developed countries'; whereas the antecedents and transactions within economic GC indicate a tendency toward such stereotypes." (Oxley \& Morris, 2013, p. 319)

In practice, researchers have identified different challenges for a 'successful' global citizenship education in the UK context. Students in Northern Ireland and England do not tend to identify themselves as global citizens (Reilly \& Niens, 2014; Sant, Davies \& Santisteban, 2016a). Whilst pre-service and in-service teachers in Wales, 
England and Northern Ireland appear to be enthusiastic about teaching global citizenship (Osler, 2011; Rielly \& Niens, 2014), they report a lack of time, resources and pedagogical and conceptual knowledge (Rielly \& Niens, 2014). As teachers do not conceive global citizenship as a priority of the curriculum, efforts are placed to other areas (Holden \& Hicks, 2007; Robbins, Francis \& Elliott, 2003).

National citizenship. In 2006, Gordon Brown started a debate on 'Britishness' which finally derived in the requirement for teachers in England to 'promote fundamental British values' (DfE, 2014). Since then, the question of national (British) identity has strongly emerged as one of the key topics of discussion on citizenship education research in England. For some, 'civic patriotism' - democracy, the rule of law, individual liberty, and mutual respect and tolerance of those with different faiths and beliefs - as encountered in the FBV guidelines is a legitimate civic aim of education for citizenship in England (Peterson, 2013). Others recommend that national identity should be treated as a 'controversial issue' (Hand \& Pearce, 2009) and that teachers should create opportunities for students to engage, reject or problematize the question of Britishness itself (Sant \& Hanley, forthcoming).

In contrast, a number of scholars have emphasized that the civic construction of Britishness as encountered in British values policies generates process of ethnic exclusion particularly in relation to the Muslim community (Arthur, 2016; Farrell, 2016; Smith, 2016). Four main reasons have been given. Jerome and Clemitshaw (2012) argue that the recent construction of 'Britishness' undermines other identities and loyalties. This is particularly notorious when 'Britishness' is directly associated with secularist values that directly clash with religious identities (Arthur, 2016). For others, the genealogy of the policy including its inscription within the anti-terrorist Prevent agenda illustrates how the policy was in itself created to exclude an ethnic 'other'. In Lander's terms (2016), "to exclude the very members of its society that are constructed as the terrorist 'Other' within and whose religious identity is racialised and conceived as the binary opposite against which the discourse of civic nationalism is constructed" (Lander, 2016, p. 276). Other researchers emphasize how the media and the public discourse have created a disjoint between Islam and Western Values being the latest necessarily associated with a "muscular assertion of Britishness" (Smith, 2016, p. 303). Finally, British values is understood in relation to neoliberal principles in which the role of teachers is the education of what is perceived to be the norm and the surveillance of those who do not conform to this norm (Farrell, 2016).

In the other three nations, the question of national identity has taken different trajectories. In Scotland, educational policy and practice focuses on a Scottish identity conceived as a modern civic identity within a globalized world (Arnot \& 
Ozga, 2010; Gamal \& Swanson, 2017). According to Hong (2015), Scottish teachers' narratives resonate with,

"the rhetoric of the official curriculum of Education for Global Citizenship (EGC) in that they emphasised several agendas of 'modern Scottish nationalism' including multiculturalism, economic prosperity, formal political literacy and engagement, especially voting, and community engagement." (p. 215)

As previously discussed, citizenship education is here partially framed by neoliberal principles. The aim is to foster the development of world-orientated citizens who want to make a (likely economic) contribution for "Scotland to flourish" particularly "through increasing sustainable economic growth" (Arnot \& Ozga, 2010, p. 344).

In Wales, similarly to Scotland, the emphasis has been placed on Welsh and global citizenship. In contrast with the Scottish case, nevertheless, Welsh identity has been essentially constructed in cultural terms (Garrat \& Piper, 2008; Kisby \& Sloam, 2012). The notion of community is here strong (Kisby \& Sloam, 2012) but the 'community' is here a 'diverse' entity. Likely in an attempt to integrate the two sub regions within Wales, the Welsh-speaking north, mid and west and the English-speaking south, citizenship is constructed in relation to the Welsh cultural community but encouraging and celebrating diversity (Garrat \& Piper, 2008).

In Northern Ireland, discussions on national identity are particularly challenging. Whilst the principal focus of the citizenship education policies is on social cohesion (Andrews \& Mycock, 2007), students in the region usually attend to segregated schools, either Catholic or Protestant (Niens et al., 2013). Thus, teachers are often left with the complicated task of fostering understanding with the Other when this Other is often absent from the school context (Barton \& Mccully, 2005). In the curriculum, peace and reconciliation are mainly examined in relation to knowledge related to history, geography, religious education and language but its emphasis on citizenship is less pronounced (Niens \& Chastenay, 2008). As previously mentioned, the curriculum encourages controversial issues as teaching and learning strategies, but empirical research suggests that Northern Irish teachers are often more likely to avoid controversial issues, not only in relation to traditional community divisions but also in relation to potential marginalized groups (Niens \& Mcllrath, 2010; Niens et al., 2013). To overcome these challenges, researchers have proposed alternative activities such as schools' collaborations (Gallagher, 2016) and participatory cross-community activities (McMurray \& Niens, 2012).

The approaches: character, citizenship and democratic education 
Despite the divergence of governmental interest across the UK or levels of attention, citizenship education is now more than ever open to theoretical and political discussions (Davies \& Chong, 2016). In this chapter, three emerging approaches to citizenship education are considered. These are, character education, democratic education and social justice education. In this section, the three approaches are defined and examined to illuminate current tensions, debates and challenges for citizenship education within a multi-national state such as the UK. It is worth noting that even if the three approaches differ in focus, implementation and political ideology, they all keep converging on the idea that citizenship education is about political engagement of young people, promoting an inclusive framework for civic identities and community understanding.

Character Education. Character Education emphasises personal morality and is broadly understood as "any approach to moral education that foregrounds the cultivation of moral character and moral virtue" (Walker, Roberts \& Kristjanson, 2015, p. 79), driven with a commitment to transform society. In other words, more in the line of civic republicanism, character education is concerned with virtue as moral excellence and the nature of a good person as make-ups of human beings.

The character education approach in the UK has been highly influenced by the North American tradition where character education is particularly prominent. Character is defined in a call from the Department for Education (DfE, 2015) inviting schools, colleges and organisation to bid for funding to support projects in character education as:

\footnotetext{
- $\quad$ perseverance, resilience and grit

- $\quad$ confidence and optimism

- $\quad$ motivation, drive and ambition

- $\quad$ neighbourliness and community spirit

- $\quad$ tolerance and respect

- $\quad$ honesty, integrity and dignity

- conscientiousness, curiosity and focus
}

These seven points could easily be aligned with the Six Pillars of character that function as the core ethical values of the USA Character Counts educational strategy (Character Counts, 2018).

Whilst the presence of character education in other European educational contexts is restricted and takes different shapes (Korim \& Hanesová, 2010), in the case of 
England, there is a special commitment from policy makers to character education that has had an impact over citizenship education:

"In 2014 policy makers have confirmed the place of citizenship education in the National Curriculum but its nature, the relative lack of attention devoted to it and the growing official commitment to character education which emphasises personal morality rather than citizenship education, suggests it has lots lot of ground". (Davies \& Chong, 2016, p. 21)

Character education has recently become a strong trend at policy level and a preference for the conservative government. Under the auspice of Nicky Morgan, the former Secretary of State for Education between 2014 and 2016, the Jubilee Centre for Character and Virtue based at the University of Birmingham ${ }^{2}$ has been nationally and internationally recognised as the leading research institution in character education. James Arthur, the director of the centre, explains their aims with the following words:

"Our vision for the Centre is not simply to research past and present attitudes to character and virtues, but shape the future attitudes and behaviours of the British people. We aim to enable British people to explore their character and virtues and, if and where required, transform them. It is as such that our prime goal is not theoretical, but practical. We intend to undertake the work with a firm belief that our programme of inter-related initiatives will make a positive transformative difference to the moral life and learning of British people. It is our belief that only by undertaking the highest possible quality research work can we serve to promote and reinforce an understanding and appreciation of moral ideals" (Arthur, n.d.)

Affiliates to this centre such as Walker, Roberts \& Kristjanson (2015) recognise some success of character education at theoretical and school-based practice, but struggling to integrate its principles at educational policy and teaching training level.

At first glance, we can see some areas of overlap between citizenship education and character education. Nevertheless, Davies, Gorard \& McGuinn (2005) warn us that a broader distinction is necessary to understand their similarities and differences. Policy makers and academics discuss this relationship too loosely, generating confusion and leading to an inappropriate use of the citizenship label. A practical example of this problem can be observed when teaching material developed from a character education approach is characterised as citizenship education and translated

\footnotetext{
${ }^{2}$ For more information about the centre, including projects and publications visit: http://www.jubileecentre.ac.uk/
} 
into the classroom space for citizenship education without further evaluation. Therefore, in the absence of a clear distinction and a full commitment from key actors to articulate clear boundaries, we will keep seeing how forms of character education are presented in the UK classrooms under the space and title of citizenship education.

It is not wrong to highlight morals, values and virtues. Moreover, some of the myths associated to character education (unclear, redundant, old-fashioned, religious, paternalistic, anti-democratic, conservative, individualistic, relative and situation dependent) has been seriously challenged (Kristjánsson, 2013). Critical voices have been raised against character education as an approach that is more concerned to conformity than social change. For this reason, it is usually associated to conservative ideologies as we can observe in the context of UK, where as previously discussed, this approach has been privileged by the Conservative government. In this case, character education is used as an ideological tool that replaces the political dimension of citizenship education (Davies \& Chong 2016) in favour of the development of the 'right' character. At the centre of the debate are practical questions on how to develop character, how to teach values or how to approach moral dilemmas to finally questioning the universality of character.

Social justice education. Social justice has been discussed for many years although it is in the past twenty years that it has re-emerged into political and educational discourses. The UK history is populated by episodes of colonialism, cultural imperialism and diverse social struggles. However, we can also find in this history some of the most remarkable events and movements in the pursuit of Social Justice. The suffragists fighting for women's right to vote or the workers organisations aiming to improve work conditions are examples of this. For authors like Miler (1999), "the quest for social justice is a natural consequence of the spread of enlightenment" (p.4) and thus is seen as part of our historical journey. Nonetheless, it is not clear that the promises of enlightenment had brought the possibility of justice (Biesta, 1998; Sant et al., 2018a). The inclusion and recognition of all members of society and its diversity are at the centre of this discussion.

These ideas resonate in the Crick report (DfEE/QCA, 1998) and were re-examined in the Parekh report (The Runnymede Trust 2000). This inclusive motivation and identity-based concern are crucial features to understand the social justice approach in a multicultural and multinational society such as the UK. Social Justice has been part of the different political agendas, receiving different level of attention and been exposed to different ideological underpinnings and shifts. Whilst we are still waiting for the new government to formalise its Social Justice position, the Labour Party has previously established the Commission for Social Justice (CSJ, 1994). In 2004, to make policy recommendations the conservatives set up the Centre for Social Justice (CfSJ, 
n.d.) and more recently, the liberal coalition published their strategy entitled Social Justice Transforming Lives (HM Government, 2012 \& 2013). Therefore, a political interest in Social Justice is evident.

'Social Justice' in citizenship education in the UK is not only ideologically conceptualized, but also constructed in multi-dimensional and multi-cause terms. Firstly, it is multi-dimensional because the understanding of justice differs in relation to different traditions used to delineate its focus. The American philosopher Nancy Fraser $(1997,2009)$ proposes three dimensions that are often used in the UK-based educational scholarship (e.g. Gewirtz, 2006; Thomas, 2012; Sant et al., 2018a). These are:

The distributive justice dimension is concerned with the way that resources and goods are distributed within society. From this perspective, social justice education contributes towards a society with equal rights, liberties and an equal distribution of social and economic resources.

The recognition justice dimension is grounded in the idea that some cultures, identities or traditions are more valued than others and are positioned in a privilege positon. From this perspective, social justice education prepare students to overcome misrecognitions caused by dominant interpretations.

- $\quad$ The participatory justice dimension focuses on the possibility of participation and influence of groups and individuals in the political life of the society. From this perspective, education should motivate and prepare individuals to get involved, using their voice and participate in the transformation of the society. Schools as social institutions play a very important role and must lead by example in their daily practices and organisation.

The relevance of each dimension in UK-based citizenship education theory and research is up to discussion. It can be argue that three dimensions of are mutually entwined and reciprocally influenced (Gewirtz, 2006) but, according to Power (2012), in the case of England, there is still a strong presence of the first two domains. Our analysis of the period 1998-2018 suggests the existence of some discussions on citizenship education and social class (e.g. Beck, 2013) and the recent impetus of the participatory dimension through discussions on 'democratic education'. But in our understanding, social justice-oriented citizenship education is particularly constructed in relation to the recognition cause.

Recognition social justice, in the citizenship education debate, is presented as 'multicause'. This is, in in relation to different social proclaims. This approach explores a range of claims and movements related to: multiculturalism, religion, ethnicity and race, gender, sexuality, disability, poverty, language diversity among others (for more 
information see: Ayers, Quinn \& Stovall, 2009). These causes are often considered on discussions on diversity and citizenship. Whilst for some, minimal common values might be necessary for the survival of any community (see, e.g. Olssen, 2004; Sant et al., 2016), others argue that citizenship education policies such as the Crick Report and more clearly the 'promotion of British Values' guidelines are not inclusive to minority groups (e.g. Elton-Chalcraft et al., 2017; Osler \& Starkey, 2011). In addition, we have seen more recently in the UK the exploration of new aspects of recognitionorientated social justice such as young people voices (Bastleer, 2011; Davies et. al. 2013;) and globalisation (Sant et. al 2018a), but also more controversial issues such as national identity (Morrice 2017; Peterson, 2013;), that touch in some of the central elements of citizenship education.

Democratic education. In an article in 2006 in the Cambridge Journal of Education, Gert Biesta and Robert Lawy (2006) argued for a shift in educational research, policy and practice from 'teaching citizenship' to 'learning democracy'. The authors explicitly identified three problems with citizenship education. First, the individualistic nature of citizenship education. For Biesta and Lawy (2006), through a neo-liberal line of thinking, the possible 'deficits' of democracy are often attributed to individual students lacking "proper knowledge and skills, the right values, and the correct dispositions to be the citizens that they should be" (p. 71). Second, the assumption that citizenship can be understood as an 'educational outcome'. Consequently, young people are place on the "problematic position of not-yet-being-a-citizen" ( $p$. 72). Further, the notion of 'citizenship' is depoliticized assuming that there is a 'right' way of being a citizen and therefore a 'right' way of teaching citizenship to young people. Third, the des-contextualized nature of citizenship education. They explain, "[e]ven where a school includes exceptional internal democratic arrangements (...) this still only represents a small proportion of the environment in and from which young people learn" (p. 73). To overcome these problems, they recommend a 'situated', communitarian and 'practical' approach that can be defined as 'democratic education'.

Either because researchers have listen to Biesta and Lawy's recommendations, or for numerous other possible reasons, there has been an impetus on research and practice on democratic education in the UK context. Indeed, three main distinctive traditions merge on the present field of 'democratic education'. In the (dominant) citizenship education tradition, democratic education is often related to the holistic and whole-school approach of citizenship education (see, e.g. Kerr et al., 2004). The concepts of 'classroom climate', 'school ethos' or 'students' participation' are key aspects within this tradition (Kerr et al., 2009). In his research examining different primary schools in Scotland, Deuchar (2009) identifies three key principles within this tradition: elected pupil councils, democratic and participative classrooms and 
discussions on controversial issues. For the author, these principles contribute to learning, engagement and citizenship outcomes. Particularly relevant in the context of UK, is the research conducted examining (school and non-school based) children and young people's councils. Whilst the councils appear to contribute towards educational purposes - research conducted on Wales and England conclude that participants in councils often learn a range of skills (Kendall, 2010; Burnitt \& Gunter, 2013) and attitudes (Crowley, 2012) -, the real power of pupils in decision-making processes is often questioned (Kay \& Tisdall, 2013; Wyness, 2009). Wyness (2009) explains,

"From previous experience, events that had been arranged by local members of parliament and councillors were seen as being tokenistic. There was also considerable criticism towards elections based on the councillors' experiences of school councils both as pupil councillors and as constituents. The electoral system in school was seen to foster elitism and bureaucracy" (p. 546).

A second tradition focuses on 'democratic schools'. Within this tradition, the Leadership and Management field often brings together liberal approaches (in the line of Amy Gutmann's (1999) 'Democratic Education') and more radical proposals developed by progressive educators such as Alexandre Neill in Summerhill. In 'Democratic schools', students and teachers are de facto involved in decision-making processes rather than been merely consulted. In contrast with more citizenshiporientated approaches where young people are considered citizens in making, in 'democratic schools', school meetings have explicit political purposes in defining how the school community organizes itself (Fielding, 2013). 'Democratic schools', however, also contribute towards educational aims. Hope (2012), for instance, examines one of the two so-called 'democratic schools' in England and concludes that democratic styles of school leadership might not only be ethically prominent but also might be more successful in learning terms. Similar results had been found by others (Trafford, 2008), issue that has fostered some to consider whether the trends towards more autonomous schools in English contexts might favour this model (Hope, 2012). However, as Hammersley-Fletcher (2014) suggest,

"what might at first appear to be a movement towards greater democracy, becomes in fact a vehicle through which teachers and schools are controlled through greater numbers of staff being responsible for improvements that have a direct influence on improved performance" ( $p$. 12).

Dewey, Arendt, Rancière and Mouffe's theories are deployed in the third, more philosophical tradition, to conceptualized new approaches to the relation between 
politics and education. Education is per se conceived as political, and politics are per se conceived as educational. As we wrote somewhere else,

"Educational settings such as schools and universities can become one (among other) political settings (...) where teachers and students participate in the political act of constructing themselves as teachers, students and as 'the people'. (...) Where educators and students can discuss whether Wall street, or the immigrants, to use Mouffe's example, are behind our problems. This would approach what Biesta (2006) has argued is the vital work of democratic education - both in providing political spaces of disagreement, and in encouraging students to learn from those moments in which they have had the opportunity (or not) to act politically in the world" (Sant et al., 2017a, p. 50).

In other words, in this tradition, the links between politics and education are unavoidable and research project aim to explore new spaces and pedagogical practices that might democratize education and might 'educationalize' politics. In line with Biesta and Lawy's (2006) recommendations, 'democratic education' is here 'situated' and 'experienced'. For instance, McDonnell (2014; 2016) argues for the relevance of arts-based practices as a way to reconnect politics and education. Whilst literature, film and television might help young people to construct and perform their political subjectivity (2014), galleries and other art spaces might allow young people to engage with more affective and corporal approaches to democratic education (2016). Following Rancière (2006) and Mouffe (1999; Laclau \& Mouffe, 2001) and later developments by Biesta (2011) and Ruitenberg (2009), conflict and antagonism are here considered essential for both democratic and educational practices. In this line, fostering conflict in educational spaces is proposed as a pedagogical practice for 'democratic education' (Sant et al., 2017b).

\section{The spaces of citizenship.}

As previously mentioned, a growing concern regarding the attitudes of young people toward civil society and political participation (Jowell \& Park, 1998) resulted in the introduction of citizenship education as a national curriculum subject in UK schools (Davies \& Chong, 2016). Since then, citizenship education has an official space within the educative system and the classroom, drawing attention to many researchers and groups interested in the way that schools and teachers prepare pupils for active and responsible citizenship (see Arthur \& Davidson, 2000; Davies, 2017; Faulks, 2006b; Keating et al., 2010; Peterson, Durrant \& Bentley, 2015). In this debate, schools are approached as spaces where the students' local experiences are contextualised in a more abstract social and political world. This is explained by Bentley (1998), 
"instruction will only be effective if it can be integrated with young people's emerging understanding and experience of themselves and the communities that they inhabit. These communities are immediate, local and particular, in contrast to more general ideas and systems, which are easily seen as remote, abstract and alien. For young people, the most obvious of these communities is the school, and I argue that as an institution this is the starting point for developing active democratic citizenship". (p. 99)

The relationship between specific communities (in which schools and individuals are embedded) and the wider social world, is paramount for citizenship education. But the place of preparing pupils for citizenship is still disputed (Peterson, Durrant $\&$ Bentley, 2015).

In the literature, some authors are particularly concerned about the possibility of moving citizenship education outside schools. Whilst they assert that the society is in itself educative, they worry that, without school-based citizenship education, the education of young citizens might be left to chance (Sant \& Davies, 2017). In the case of England, where the trust-lead National Citizenship Service (NCS) (and not the schools) is expected to provide opportunities for young people's community involvement, there is doubts about the ability of trusts and community organizations to actively engaging with students with more reflective and informed practices (Davies \& Chong, 2016).

Others, in contrast, argue that research on citizenship education cannot be constrained to discussions concentrated on schools elements of formal education. The social nature of the subject and the diverse interest from researchers, community groups and policy makers demands a more open discussion that goes beyond the classroom space, the traditional school structure and individualistic conceptualisations of young people. In this perspective, Biesta and Lawy (2006) clarify that schools can only be the departure point for citizenship education if they "focus on young people-in-context and on the social, economic, cultural and political context(s) in which they live their lives" (p. 75). From the analysis of recent initiatives in citizenship education in the UK and as previously discussed in this chapter, these authors argue that the problem of citizenship in schools is "teaching about citizenship". In other words, rather than understanding how young people navigate through different contexts and socio-political spaces that determine their perceptions, teaching about citizenship presents a depoliticised framework that focuses on producing good citizens without a deeper exploration. This is problematic because as Biesta and Lawy (2006) explain:

"It is only by following young people as they move in and out of different contexts, practices and institutions and by trying to understand what they 
learn from their participation, or nonparticipation, in these contexts, that we can actually begin to understand what is going in the lives of young citizens in Britain today".(pp.75-76)

This perspective has led to a growing interest on exploring alternative spaces for citizenship education. A first example of this form of research can be found in the study carried out by Lawy, Biesta, McDonnell and Lawy (2010) that explains how some forms of citizenship education and democratic learning that happen outside the school and curriculum context (in this case, in gallery education projects) contribute to develop alternative forms of civic and democratic understanding. The transition from school to a different social space:

"required young people to 'unlearn' certain actions and behaviours and to 'learn' others at the same time the aim being to achieve a position where young people felt sufficiently trusted that they could begin to take ownership and full responsibility for their own action" (Lawy et al., 2010, p. 363).

A second example is the European research project Partispace (Bastleer et al. 2017). This study presents a wide range of rich case studies that illustrate spaces and styles of participation of young people from eight major European cities. From the UK case studies included in this major research project, we can observe that young people do participate in multiple ways notwithstanding the misrecognition from some authorities. There is also a sense that educational institutions are struggling to enable spaces for social and political engagement of young people and this point demands more attention from researchers interested in spaces associated to citizenship education.

Perhaps as a compromise between the more school-based and the more community-based perspectives, some argue for a research that examines the intersection of these spaces (Percy-Smith \& Thomas, 2010). For instance,

Davies et al. (2013), in a review of the literature, agree with the idea that more research that bridges the gap between schools, communities and young people perceptions is needed in the UK.

\section{Conclusions}

In this chapter, we have examined general policy, theory and research trends on citizenship education in the UK context for the period 1998-2018. We have discussed how citizenship education, as represented in the influential Crick Report (QCA, 1998), has developed into distinctive forms and approaches for each of the four UK Nations. Citizenship education has here been examined in relation to possible dimensions (i.e. global and national), approaches (i.e. character, social justice and democratic education) and spaces. We now would like to contrast these different sections to 
illuminate some key issues for citizenship education in the UK and how these can help us to understand what might happen everywhere else.

First, our examination suggests a movement from one 'citizenship education' to multiple 'citizenship educations'. The Crick's framework (QCA, 1998), based on liberal and social-democratic principles, had a strong influence on the English citizenship education policy as well as a clear impact on the policy of the other three nations. During the period studied, nevertheless, this influence has weakened under the pressure of other competing perspectives. In terms of policy-making, more conservative ideologies had favoured a more republican and value-based character education where conformity rather than change is a key feature. The dominant neoliberalist discourse in education has also challenged the traditional liberal approach to citizenship education policy. From this later perspective, citizenship education might be economically instrumentalized with topics such as 'financial literacy' replacing the traditional political nature of citizenship studies.

Simultaneously, theory and research on citizenship education has partially shifted towards more radical positions. Multiculturalist, cosmopolitalist and post-colonialist scholars have argued against the centrality of a citizenship education policy that they understand to reproduce imperialist values and exclude the same members of the community. Post-structuralist and pragmatist authors have claimed for a citizenship education that abandons the prevalence of school practices and that open the doors to alternative relations between 'citizenship' and 'education'. Although we value and appreciate this multiplicity of discourses, we also wonder whether this strengthening of views might challenge the possibility of a present and future citizenship education policy that, in the line of the Crick Report, brings together academics and policymakers.

Second, the analysis of the global and national dimension of citizenship education illustrates, in our understanding, one of the key challenges for citizenship education: the question of the community. The nation-state as a key dimension for citizenship education has been often criticized for its tendency to homogeneity and conformity. In the UK, we have found examples of this on the critiques to English and Scottish citizenship education policies (e.g. Elton-Chalcraft et al., 2017; Gamal \& Swanson, 2017; Osler \& Starkey, 2001). In this respect, more cosmopolitan identities have been promoted as alternatives (see e.g., Osler \& Starkey, 2003). But the examination of more globally orientated discourses on citizenship education also illustrate similar challenges (e.g. Swanson \& Pashby, 2016; Oxley \& Morris, 2013) as well as challenges related to neoliberal understandings of the globalization process (Oxley \& Morris, 2013; Arnot \& Ozga, 2010). In this respect, we wonder whether the challenge for the citizenship education academic community is not that citizenship is constructed in relation to any particular community (e.g. the nation-state, for instance, in Sant et al., 
2016b). But rather, the fact that all communities appears to be nowadays diverse and finding common (non exclusive) bounds among their citizens is increasingly difficult.

Third, diversity appears to be the general norm on the theoretical, ideological and practical discussions around citizenship education in the UK. In this respect, to understand 'local' students, citizenship education needs to be situated and contextualized in the lives of these particular students (Biesta \& Lawy, 2006). Projects such as Partispace (Bastleer et al. 2017) can help us to understand how young people make political sense of their daily lives as citizens of their local communities. But we argue that school-based citizenship education research also needs to be situated on the 'local' schools. Under the diversity of provision for school-based citizenship education, research projects could help schools to examine what is the best approach considering in situ the characteristics of the student body and voice.

We feel that a range of place-based approaches to citizenship education could respond to the situation we have presented here but we argue that for this to happen, three conditions need to be meet. First, even in a context of theoretical and practical diversity, citizenship education needs to be defined as a priority within the curriculum. An "indecisive" approach (Faulks, 2006a) is likely to leave to chance the education of young citizens. Second, 'situated' approaches require good knowledge of each case. In this respect, educational budgets should contemplate funding for intensive educational research that allows researchers to provide an in depth account of how young people make sense of their political life inside and outside schools. Third, and in relation to the previous point, there is a need to reinforce the channels of discussion for knowledge exchange. 'Good knowledge', we argue, is not only academic knowledge. If citizenship education is conceived, as we do, as the education of the citizenry by the citizenry, the debate needs to be open to all, policymakers, academics, teachers, practitioners and young people. Then, openness and multivocality become the corner stone of impending local conceptualisations of citizenship education.

\section{References}

Andrews, R., \& Mycock, A. (2007). Citizenship education in the UK: Divergence within a multi-national state. Citizenship Teaching and Learning, 3(1), 73-88

Arnott, M., \& Ozga, J. (2010). Education and nationalism: the discourse of education policy in Scotland. Discourse: Studies in the Cultural Politics of Education, 31(3), 335350.

Arthur, J. (n.d.) Welcome from Centre Director . Retreived from http://www.jubileecentre.ac.uk/356/about/welcome-from-centre-director 
Arthur, J. (2015). Extremism and neo-liberal education policy: A contextual critique of the Trojan horse affair in Birmingham schools. British Journal of Educational Studies, 63(3), 311-328.

Arthur, J. \& Davidson, J. (2000). Social literacy and citizenships education in the school curriculum. The curriculum Journal, 11 (1), 9-23.

Ayers, W., Quinn, T. \& Stovall, D. (Eds.) (2009). Handbook of Social Justice in Education. London, UK: Routledge.

Barton, K. C., \& Mccully, A. W. (2005). History, identity, and the school curriculum in Northern Ireland: an empirical study of secondary students' ideas and perspectives. Journal of Curriculum Studies, 37(1), 85-116.

Batsleer, J., Ehrensperger, K., Lüküslü, D., Osmanoğlu, B., Pais, A., Reutlinger, C., Roth, P., Wigger, A. \& Zimmerman, D. (2017). Claiming spaces and struggling for recognition: Youth participation through local case studies. (Retrived from: https://zenodo.org/record/1064119\#.WoxJ8iXwbIU) Access: 20 Feb 2018)

Batsleer, J. (2011). Voices from an edge. Unsettling the practices of youth voice and participation: arts-based practice in The Blue Room, Manchester. Pedagogy, Culture \& Society, 19(3), 419-434

Beck, J. (2013). Powerful knowledge, esoteric knowledge, curriculum knowledge. Cambridge Journal of Education, 43(2), 177-193.

Bentley, T. (1998). Learning Beyond the Classroom. Oxon, UK: Routledge

Biesta, G. (1998). Deconstruction, justice and the question of education. Zeitschrift Für Erziehungswissenschaft, 1, 395-411.

Biesta, G. (2008). What kind of citizen? What kind of democracy? Citizenship education and the Scottish Curriculum for Excellence. Scottish Educational Review, 40(2), 38-52.

Biesta, G. (2011). The Ignorant Citizen: Mouffe, Ranciere, and the Subject of Democratic Education. Studies in philosophy and education, 30(2), 141-153.

Biesta, G., \& Lawy, R. (2006). From teaching citizenship to learning democracy: overcoming individualism in research, policy and practice. Cambridge Journal of Education, 36(1), 63-79.

Burnitt, M., \& Gunter, H. (2013). Primary school councils: Organization, composition and head teacher perceptions and values. Management in Education, 27(2), 56-62. 
Camicia, S. P., \& Franklin, B. M. (2011). What type of global community and citizenship? tangled discourses of neoliberalism and critical democracy in curriculum and its reform. Globalisation, Societies and Education, 9(3-4), 311-322.

CfSJ (N.D) Centre for Social Justice. Retrived from:

https://www.centreforsocialjustice.org.uk/

Colley, L. (2007). Does Britishness Still Matter in the Twenty-First Century-and How Much and How Well Do the Politicians Care? The Political Quarterly, 78(s1), 21-31.

Cowan, E. M., \& McMurtry, D. C. (2009). The implementation of 'Education for Citizenship' in schools in Scotland: A research report. The Curriculum Journal, 20(1), 61-72.

Crowley, S. (2012). Is anyone listening? The impact of children's participation on policy making. Doctoral dissertation, Cardiff University

CSJ (Commission for Social Justice) (1994). Social Justice: Strategies for national renewal. London, UK: Verso.

Davies, I. (2016). United Kingdom. In Peterson, A., Davies, I., Chong, K. M., Epstein, T., Peck, C. L., Ross, A., ... \& Sonu, D. (Ed.). Education, globalization and the nation (pp. 103-124). Springer.

Davies, I. (2017). Comparative Insights on Civics and Citizenship Education and the Curriculum: A View from England, In A. Peterson \& L. Tudball (eds.) Civics and citizenship education in Australia: challenges, practices and international perspectives. (pp. 207-223). Sydney, Australia: Bloomsbury Academic

Davies, I., \& Chong, E. K. (2016). Current challenges for citizenship education in England. Asian Education and Development Studies, 5(1), 20-36.

Davies, I., Hampden-Thompson, G., Calhoun, J., Bramley, G., Tsouroufli, M., Sundaram, V.,Lord, P. \& Jeffes, J. (2013). Young People's Community Engagement: What Does Research-Based and Other Literature Tell us About Young People's Perspectives and the Impact of Schools' Contributions? British Journal of Educational Studies, 61(3), 327-343.

Davies, I., Evans, M., \& Reid, A. (2005). Globalising Citizenship Education? a Critique of "Global Education" and "Citizenship Education." British Journal of Educational Studies, 53(1), 66-89.

Davies, I., \& Issitt, J. (2005). Reflections on citizenship education in Australia, Canada and England. Comparative Education, 41(4), 389-410. 
Department for Education and Employment/Qualifications and Curriculum Authority (DfEE/ QCA) (1999) Education for citizenship and the teaching of democracy in schools. London: QCA.

Department for Education (DfE) (2005). Developing the global dimension in the school curriculum, http://www.education.gov.uk/publications/eOrderingDownload/14092005DOC-EN-02.doc

Department for Education (DfE) (2014). Promoting fundamental British values through SMSC, https://www.gov.uk/government/publications/promoting-fundamentalbritish-values-through-smsc

Deuchar, R. (2009). Seen and Heard, and Then Not Heard: Scottish Pupils' Experience of Democratic Educational Practice during the Transition from Primary to Secondary School. Oxford Review of Education, 35(1), 23-40.

Elton-Chalcraft, S., Lander, V., Revell, L., Warner, D., \& Whitworth, L. (2017). To promote, or not to promote fundamental British values? Teachers' standards, diversity and teacher education. British Educational Research, 43 (1), 29-48.

Farrell, F. (2016). Why all of a sudden do we need to teach fundamental British values? A critical investigation of religious education student teacher positioning within a policy discourse of discipline and control. Journal of Education for Teaching, 42(3), 280-297.

Farthing, R. (2010). The politics of youthful antipolitics: representing the "issue" of youth participation in politics. Journal of Youth Studies, 13(2), 181-195.

Faulks, K. (2006a). Rethinking citizenship education in England: some lessons from contemporary social and political theory. Education, citizenship and social justice, 1(2), $123-140$

Faulks, K. (2006b) Education for citizenship in English Schools: a critique of current practice. Journal of education policy, 21 (1), 59-74.

Fielding, M. (2013). Whole School Meetings and the Development of Radical Democratic Community. Studies in Philosophy and Education, 32(2), 123-140.

Fraser, N. (1997). Justice interruptus: critical reflections on the "postsocialist" condition. New York, USA: Routledge

Fraser, N. (2009) Scales of Justice: Reimagining Political Space in a Globalizing World. New York, USA: Columbia University Press.

Gamal, M., \& Swanson, D. M. (2017). Nation state, popul (ar) ism, and discourses of global citizenship: examples from Scotland's Curriculum for Excellence. . In Y. Akbaba 
\& B. Jeffrey (ed.) The implications of 'New Populism' For Education (pp. 21-40). Gloucestshire, UK: E\&E.

Garratt, D. \& Piper, H. (2008). Citizenship education in England and Wales: theoretical critique and practical considerations. Teachers and Teaching, 14(5-6), 481-496.

Gewirtz, S. (2006). Conceptualizing social justice in education: mapping the territory. Journal of Education Policy, 13(4), 469-484.

Gutmann, A. (1999). Democratic education. Chichester, USA: Princeton University Press.

Hammersley-Fletcher, L. (2014). Educational Austerity and Critical Consciousness: English Primary School Leaders wrestling with Educational Policy shifts. Éducation comparée, 12.

Hand, M., \& Pearce, J. (2009). Patriotism in British schools: Principles, practices and press hysteria. Educational Philosophy and Theory, 41(4), 453-465.

HM Government (2012). Social Justice: transforming lives. London: Stationery office.

HM Government (2013). Social Justice: transforming lives One year on. London: Stationery office.

Holden, C., \& Hicks, D. (2007). Making global connections: The knowledge, understanding and motivation of trainee teachers. Teaching and Teacher Education, 23(1), 13-23.

Hong, B. P. (2015). Young people's experience of a democratic deficit in citizenship education in formal and informal settings in Scotland. Unpublished PhD Dissertation.

Hope, M. A. (2012). The Importance of Belonging: Learning from the Student Experience of Democratic Education. Journal of School Leadership, 22(4), 733-750.

Husbands, C. (2007). Educación para la ciudadanía en una Europa diversificada: tensiones y dificultades sobre la educación para la ciudadanía en entornos urbanos transculturales. Enseñanza de Las Ciencias Sociales, 6, 139-146.

Jerome, L., \& Clemitshaw, G. (2012). Teaching (about) Britishness? An investigation into trainee teachers understanding of Britishness in relation to citizenship and the discourse of civic nationalism. The Curriculum Journal, 23(1), 19-41.

Kay, M. \& Tisdall, E. (2013). The Transformation of Participation? Exploring the Potential of "Transformative Participation" for Theory and Practice around Children and Young People's Participation. Global Studies of Childhood, 3(2), 183.

Keating, A., Kerr, D., Benton, T., Mundy, E., \& Lopes, J. (2010). Citizenship education in England 2001-2010: young people's practices and prospects for the future: the eighth 
and final report from the Citizenship Education Longitudinal Study (CELS). Department for Education

Kendall, S. (2010). Children and young people's participation in Wales (Research Report No: 051/2010). Cardiff: Welsh Assembly Government.

Kerr, D. (2005). Promoting active citizenship in schools and communities in England: emerging lessons from policy, practice and research. In B. Maes (Ed.) Different faces of citizenship Development of citizenship education in European countries (pp. 91-125). Sint-Katelijne-Waver: CIDREE

Kerr, D., Ireland, E., Lopes, J. \& Craig, R. (2004). Citizenship Education Longitudinal Study: Second Annual Report: First Longitudinal Survey making citizenship education real. NFER: Nottingham. Retrieved from https://www.education.gov.uk/publications/eorderingdownload/rr531.pdf

Kerr, D., Sturman, L., Schulz, W. \& Burge, B. (2009). ICCS 2009 European Report. IEA: Amsterdam.

Kisby, B., \& Sloam, J. (2011). Citizenship, democracy and education in the UK: Towards a common framework for citizenship lessons in the four home nations. Parliamentary Affairs, 65(1), 68-89.

Kitchen, D. (2005). Patterns in developing citizenship in Wales. In B. Maes (Ed.) Different faces of citizenship Development of citizenship education in European countries (pp. 127-146). Sint-Katelijne-Waver: CIDREE

Laclau, E. \& Mouffe, C. (2001). Hegemony and Socialist Strategy. London, UK: Verso.

Lander, V. (2016). Introduction to fundamental British values. Journal of Education for Teaching, 42(3), 274-279.

Lawy, R., Biesta, G., McDonnell, J., \& Lawy, H. (2008). The art of democracy: Gallery education and young people's democratic learning. British Educational Research Journal, 36(3), 351-365.

Maes, B. \& Vanheeswijck, H. (2005). Education for citizenship in Flanders,. In B. Maes (Ed.) Different faces of citizenship Development of citizenship education in European countries (pp. 147-164). Sint-Katelijne-Waver: CIDREE

Maitles, H. (2010). Citizenship initiatives and pupil values: A case study of one Scottish school's experience. Educational Review, 62(4), 391-406.

Mannion, G., Biesta, G., Priestley, M., \& Ross, H. (2011). The global dimension in education and education for global citizenship: genealogy and critique. Globalisation, Societies and Education, 9(3-4), 443-456. 
Marshall, H. (2011). Instrumentalism, ideals and imaginaries: theorising the contested space of global citizenship education in schools. Globalisation, Societies and Education, 9(3-4), 411-426.

McDonnell, J. (2014). Finding a Place in the Discourse: Film, Literature and the Process of Becoming Politically Subject. Journal of Social Science Education, 13(4), 78-86.

McDonnell, J. (2016). Is it "all about having an opinion"? Challenging the Dominance of Rationality and Cognition in Democratic Education via Research in a Gallery Setting. International Journal of Art and Design Education (online) http://doi.org/10.1111/jade.12107

McLaughlin, T. H. (2000). Citizenship education in England: The Crick report and beyond. Journal of philosophy of education, 34(4), 541-570.

McMurray, A., \& Niens, U. (2012). Building bridging social capital in a divided society: The role of participatory citizenship education. Education, Citizenship and Social Justice, 7(2), 207-221.

Miller, D. (1999). Principles of social justice. Cambridge, Mass and London: Harvard University Press

Morrice, L. (2017). British citizenship, gender and migration: the containment of cultural differences and the stratification of belonging. British Journal of Sociology of Education, 38 (5): 597-609

Mouffe, C. (1999). Deliberative Democracy or Agonistic. Social Research, 66(3), 745 758.

Munn, P., \& Arnott, M. (2009). Citizenship in Scottish schools: The evolution of education for citizenship from the late twentieth century to the present. History of Education, 38(3), 437-454.

Niens, U., \& Chastenay, M. H. (2008). Educating for peace? Citizenship education in Quebec and Northern Ireland. Comparative education review, 52(4), 519-540.

Niens, U., \& Mcllrath, L. (2010). Understandings of citizenship education in Northern Ireland and the Republic of Ireland: Public discourses among stakeholders in the public and private sectors. Education, Citizenship and Social Justice, 5(1), 73-87.

Niens, U., O'Connor, U., \& Smith, A. (2013). Citizenship education in divided societies: teachers' perspectives in Northern Ireland. Citizenship Studies, 17(1), 128-141.

Ofsted (2005). Citizenship in secondary schools: evidence from Ofsted inspections (2003/04).

http://dera.ioe.ac.uk/5244/1/Citizenship\%20in\%20secondary\%20schools\%20evidence 
\%20from\%20Ofsted\%20inspections\%20\%28200304\%29\%20\%28PDF\%20format\%29. pdf

Olssen, M. (2004). From the Crick Report to the Parekh Report: multiculturalism, cultural difference, and democracy-the re-visioning of citizenship education1. British Journal of Sociology of Education, 25(2), 179-192.

Osler, A. (2011). Teacher interpretations of citizenship education: National identity, cosmopolitan ideals, and political realities. Journal of curriculum studies, 43(1), 1-24.

Osler, A. \& Starkey, H. (2001). Citizenship education and national identities in France and England: inclusive or exclusive? Oxford Review of Education, 27(2), 287-305.

Osler, A., \& Starkey, H. (2003). Learning for cosmopolitan citizenship: theoretical debates and young people's experiences. Educational Review, 55(3), 243-254.

Oxley, L., \& Morris, P. (2013). Global Citizenship: A Typology for Distinguishing its Multiple Conceptions. British Journal of Educational Studies, 61(3), 301-325.

Osler, A. (2009). Citizenship education, democracy and racial justice 10 years on. Race Equality Teaching, 27(3), 21-27.

Peterson, A. (2013). Civic patriotism as a legitimate aim of education for citizenship in England. Citizenship Teaching \& Learning, 8(1), 5-20.

Peterson, A., Durrant, I., \& Bentley, B. (2015). Student teachers' perceptions of their role as civic educators: evidence from a large higher education institution in England. British Educational Research Journal, 41(2), 343-364.

Phillips, R. (2003). Education policy, comprehensive schooling and devolution in the disUnited Kingdom: an historical' home. Journal of Education Policy, 18(1), 1-17.

Phillips, R. (2004). Culture, community and curriculum in Wales: Citizenship education for the new democracy. In Lawton, D., Cairns, J., \& Gardner, R. (Ed). Education for Citizenship. (pp. 151-161). London, UK: A\&C Black

Power, S. (2012) From redistribution to recognition to representation: social injustice and the changing politics of education. Globalisation, Societies and Education, 10 (4): 473-492.

Rancière, J. (2006). Hatred of Democracy. London, UK: Verso.

Reilly, J., \& Niens, U. (2014). Global citizenship as education for peacebuilding in a divided society: structural and contextual constraints on the development of critical dialogic discourse in schools. Compare: A Journal of Comparative and International Education, 44(1), 53-76. 
Robbins, M., Francis, L., \& Elliott, E. (2003). Attitudes toward education for global citizenship among trainee teachers. Research in Education, 69, 93-98.

Rodrigo, G. L. (2007). El concepto de ciudadanía, la historia y el territorio como factores de la educación ciudadana en Francia e Inglaterra. In R. M. Ruiz, R. L Atxurra $\&$ E. F. de Larrea, (Ed). Las competencias profesionales para la enseñanza-aprendizaje de las Ciencias Sociales ante el reto europeo y la globalización (pp. 321-334). Bilbao, Spain: AUPDCS.

Ruitenberg, C. (2009). Educating political adversaries: Chantal Mouffe and radical democratic citizenship education. Studies in Philosophy and Education, 28(3), 269281.

The Runnymede Trust (2000) The future of multy-ethnic Britain: the Parekh report. London, UK: Profile books.

Sant, E., Davies, I., Pashby, K. \& Shultz, L. (2018b). Global Citizenship Education: A Critical Introduction to Key Concepts and Debates. London, UK: Bloomsbury Publishing.

Sant, E., Davies, I. \& Santisteban, A. (2016a). Citizenship and Identity: the self-image of secondary school students in England and Catalonia. British Journal of Educational Studies, 64 (2), 235-260.

Sant, E., Santisteban, A., Pagès, J., González-Monfort, N., \& Oller, M. (2016b) How do catalan students narrate the history of Catalonia when they finish primary education?, McGill Journal of Education, 5(2/3), pp.341-362.

Sant, E., \& Davies, I. (2017). Promoting participation at a time of social and political turmoil: what is the impact of children's and young people's city councils?.

Cambridge Journal of Education, 1-17.

Sant, E. \& Hanley, C. (forthcoming). Political assumptions underlying pedagogies of national education: the case of student teachers teaching 'British Values' in England. British Educational Research Journal

Sant, E., Pais, A., McDonnell, J. \& Menendez, D. (2017a). Social fantasy vs. Radical Democracy: two competing concepts of Populism and how they Challenge Education. In Y. Akbaba \& B. Jeffrey (ed.) The implications of 'New Populism' For Education (pp. 41-52). Gloucestshire, UK: E\&E.

Sant, E., McDonnell, J., Pashby, K., Menendez Alvarez-Hevia, D., Hanley, C. (2017b) Pedagogies Of Agonistic Democracy And Global Citizenship Education. In: ECER 2017. 
Sant, E., Lewis, S., Delgado, S. \& Ross, E.W. (2018a) Justice and global citizenship. In Davies, I., Ho, L. C., \& Kiwan, D., Peck, C., Peterson, A., Sant, E., Waghid, Y., (Ed.) The Palgrave Handbook of Global Citizenship and Education (pp. 227-244). London: Palgrave Macmillan

Seth-Smith, N. (2013). UKIP and the rise of English nationalism. Open Democracy UK. https://www.opendemocracy.net/ourkingdom/niki-seth-smith/ukip-and-rise-ofenglish-nationalism

Smith, A. (2003). Citizenship Education in Northern Ireland: Beyond national identity?, Cambridge Journal of Education, 33(1), 15-32.

Smith, H. J. (2016). Britishness as racist nativism: a case of the unnamed "other." Journal of Education for Teaching, 42(3), 298-313.

Swanson, D. M., \& Pashby, K. (2016). Towards a critical global citizenship?: a comparative analysis of GC education discourses in Scotland and Alberta. Journal of Research in Curriculum Instruction, 20(3), 184-195

Thomas, N. (2012). Love, rights and solidarity: Studying children's participation using Honneth's theory of recognition. Childhood, 19(4), 453-466.

Trafford, B. (2008). Democratic Schools: Towards a Definition. In J. Arthur, I. Davies \& C. Hahn (Ed.) SAGE handbook of education for citizenship and democracy (pp. 410423). London, UK: Sage Publications Ltd.

Welsh Assembly, Department for Children, Education, Lifelong Learning and Skills (2008a) Personal and social education framework for 7 to 19-year-olds in Wales.

Cardiff: Department for Children, Education, Lifelong Learning and Skills.

http://learning.gov.wales/docs/learningwales/publications/130425-personal-andsocial-education-framework-en.pdf

Welsh Assembly, Department for Children, Education, Lifelong Learning and Skills (2008b). Education for Sustainable Development and Global Citizenship. A Common Understanding for Schools. Cardiff: Department for Children, Education, Lifelong Learning and Skills.

http://learning.gov.wales/docs/learningwales/publications/081204commonunderstsc hoolsen.pdf

Wyness, M. (2009). Children Representing Children: Participation and the problem of diversity in UK youth councils. Childhood, 16(4), 535-552. 